\title{
Misvisende om kosthold i ny nasjonal retningslinje for forebygging av hjerte- og karsykdommer
}

DEBATT

\section{INGUNN NARVERUD}

E-post: ingunn.narverud@medisin.uio.no Ingunn Narverud og Jacob J. Christensen har bidratt likt til denne artikkelen. Ingunn Narverud (f. 1983) er ph.d. og klinisk ernæringsfysiolog. Hun er ansatt ved Avdeling for ernæringsvitenskap, Institutt for medisinske basalfag, Universitetet i Oslo, og ved Nasjonal kompetansetjeneste for familiær hyperkolesterolemi, Oslo universitetssykehus. Forfatter har fylt ut ICMJE-skjemaet og oppgir ingen interessekonflikter.

\section{JACOB J. CHRISTENSEN}

Ingunn Narverud og Jacob J. Christensen har bidratt likt til denne artikkelen. Jacob J. Christensen (f. 1986) er m.sc. og klinisk ernæringsfysiolog. Han arbeider ved Avdeling for ernæringsvitenskap, Institutt for medisinske basalfag, Universitetet i Oslo.

Forfatter har fylt ut ICMJE-skjemaet og oppgir følgende interessekonflikter: Han har vært nestleder i Kliniske ernæringsfysiologers forening tilsluttet Forskerforbundet (KEFF) siden 2015.

\section{INGER O. OTTESTAD}

Inger O. Ottestad (f. 1967) er ph.d. og klinisk ernæringsfysiolog. Hun er ansatt ved Avdeling for ernæringsvitenskap, Institutt for medisinske basalfag, Universitetet i Oslo. Forfatter har fylt ut ICMJE-skjemaet og oppgir ingen interessekonflikter.

\section{STINE M. ULVEN}

Stine M. Ulven (f. 1970) er ph.d. og professor i klinisk ernæring ved Avdeling for ernæringsvitenskap, Institutt for medisinske basalfag, Universitetet i Oslo.

Forfatter har fylt ut ICMJE-skjemaet og oppgir følgende interessekonflikter: Hun har de siste fem år mottatt forskningsbidrag fra Mills DA, TINE BA and Olympic seafood/Rimfrost.

\section{KIRSTEN B. HOLVEN}

Kirsten B. Holven (f. 1963) er ph.d. og professor i klinisk ernæring. Hun har hovedstilling som professor ved Avdeling for ernæringsvitenskap, Institutt for medisinske basalfag, Universitetet i Oslo, og bistilling som forskningsansvarlig ved Nasjonal kompetansetjeneste for familiær hyperkolesterolemi, Oslo universitetssykehus.

Forfatter har fylt ut ICMJE-skjemaet og oppgir følgende interessekonflikter: Hun har mottatt honorar fra Amgen, Pronova og Sanofi og forskningsbidrag fra TINE SA, Mills SA, Olympic Seafood, Amgen, Sanofi og Kaneka,

Det er gledelig å se at Nasjonal faglig retningslinje for forebygging av hjerte- og karsykdom er blitt oppdatert. Vi mener imidlertid at den lider av tre alvorlige svakheter: Nasjonale og internasjonale anbefalinger og føringer om inntak av mettet fett settes til side, 
middelhavskostholdet får uforholdsmessig stor plass og en manglende systematisk tilnærming til kunnskapsgrunnlaget.

I 2011 og 2016 ble henholdsvis Kostråd for å fremme folkehelsen og forebygge kroniske sykdommermetodologi og vitenskapelig kunnskapsgrunnlag og 2016 European Guidelines on Cardiovascular Disease Prevention in Clinical Practice publisert $(1,2)$. Rapporten Kostråd om fett - en oppdatering og vurdering av kunnskapsgrunnlaget ble publisert i 2017 (3). De tre oppsummeringene vektlegger begrensning av inntaket av mettet fett som et av de viktigste tiltakene for å forebygge hjerte- og karsykdom.

Nyere kostundersøkelser har vist at omkring 14 energiprosent av nordmenns samlede matinntak kommer fra mettet fett (3). Det er fire energiprosent over anbefalingene gitt i de norske kostrådene (1). Det har ført til at regjeringen i Nasjonal handlingsplan for bedre kosthold (2017-2021) har satt et langsiktig og oppnåelig mål om å redusere innholdet av mettet fett i kostholdet til 12 energiprosent. Helseministeren har allerede initiert et samarbeid med matindustrien for å oppnå dette målet (4).

Retningslinjen legger Helsedirektoratets kostråd til grunn (5). Allikevel er det svært betenkelig at nasjonale og internasjonale retningslinjer om inntak av mettet fett er blitt satt til side til fordel for en gjennomgående anbefaling av middelhavskosthold. I retningslinjen trekker arbeidsgruppen frem at «kvaliteten på dokumentasjonen vurderes som svak» (5, s. 38) og at sammenhengen mellom mettet fett og hjerte- og karsykdom ikke er entydig (5, s. 37).

Dette står i skarp kontrast til det overbevisende kunnskapsgrunnlaget i nasjonale og internasjonale anbefalinger. Dessuten går det imot politiske føringer, der mettet fett i kostholdet trekkes frem som en svært sentral faktor i sammenheng med hjerte- og karsykdom.

\section{LDL-kolesterolnivå, mettet fett og hjerte- og karsykdom}

Sammenhengen mellom LDL-kolesterolnivå, hjerte- og karsykdom og mettet fett kan oppsummeres gjennom fire forskningsspørsmål.

Forårsaker høyt LDL-kolesterolnivå utvikling av hjerte- og karsykdom? Ja, det gjør det. Det er solid dokumentasjon på at forhøyet LDL-kolesterolnivå er kausalt knyttet til økt risiko for hjerteog karsykdom (6). Mennesker med genetisk årsak til forhøyet nivå har mer hjerte- og karsykdom og mennesker med genetisk årsak til lavere kolesterolnivå har mindre.

LDL-kolesterolet har vært pekt ut som en viktig risikofaktor siden Framingham-studiens spede begynnelse. Lenge har høyt LDL-kolesterolnivå vært ansett som den viktigste enkeltfaktoren for utvikling av aterosklerose, den underliggende patologiske prosessen som fører til hjerte- og karsykdom.

Kan man påvirke graden av hjerte- og karsykdom ved å påvirke LDL-kolesterolnivået? Ja, det kan man $(6,7)$.Vi har nå flere typer medikamenter som påvirker LDL-kolesterolnivået og graden av hjerte- og karsykdom. Statiner er spesielt godt studert. Disse reduserer produksjonen av kolesterol i leveren og senker dermed LDL-kolesterolnivået i blodet.

I en lang rekke studier er det vist at statiner reduserer risikoen for hjerte- og karsykdom. Intervensjoner som varer i omkring fem år viser at risikoen for slik sykdom synker med $20 \%$ per mmol/l reduksjon i LDL-kolesterolnivå (8). Dersom reduksjonen varer lenger enn dette, er risikoreduksjonen mer uttalt, opp mot 50 \% i studiene som varer over 50 år (6). Viktigst av alt: Uansett om du reduserer LDL-kolesterolnivået med medikamenter, kosthold eller er genetisk disponert for et lavere nivå, er reduksjonen direkte knyttet til endringen i risikoen for hjerte- og karsykdom.

Påvirker mettet fett $i$ kostholdet LDL-kolesterolnivået $i$ blodet? Ja, det gjør det (9-12). Dette vet vi fra såkalte metabolske studier, studier der vi vet nøyaktig hva deltagerne har spist under helt kontrollerte forhold. 
Jo mer mettet fett, transfett og kolesterol man får i seg, desto mer øker LDL-kolesterolnivået. På den annen side vil økt inntak av umettet fett (særlig omega-6-flerumettede fettsyrer) senke LDL-kolesterolnivået i blodet.

Vil et redusert inntak av mettet fett beskytte mot hjerte- og karsykdom? Ja, det vil det (13). Det er gjennomført et stort antall kostintervensjoner der forskerne har byttet ut mettet fett med umettet fett i kostholdet til forsøkspersoner. Et knippe av disse har svært høy kvalitet. I de beste studiene har man klart å redusere LDL-kolesterolet i mange år og dermed oppnådd en betydelig beskyttelse mot hjerte- og karsykdom.

Kunnskapsgrunnlaget bak disse fire forskningsspørsmålene er overbevisende. Dette er hovedårsaken til at alle internasjonale anbefalinger for forebygging og behandling av hjerte- og karsykdom primært retter oppmerksomheten mot reduksjon av LDLkolesterolnivået ved å begrense inntaket av mettet fett i et ellers sunt kosthold.

\section{Feil vektlegging i retningslinjene}

Arbeidsgruppen hevder: «Sammenhengen mellom mettet fett og hjerte- og karsykdom er likevel ikke entydig, ettersom også HDL-kolesterol og triglyserider påvirkes» (5, s. 37). Vi vil her poengtere at effekten på HDL-kolesterolnivået ikke bør vurderes i denne sammenheng. Medikamenter eller naturlige mutasjoner som øker HDL-kolesterolnivået er ikke vist å redusere risikoen for hjerte- og karsykdom. Ut fra dagens kunnskap eksisterer det altså ikke noe grunnlag for å si at mettet fett har positiv effekt på risikoen for hjertesykdom selv om det $ø$ ker HDL-kolesterolnivået. Vi kan heller ikke hevde at et lavere nivå av HDL-kolesterol som følge av mindre inntak av mettet fett, har konsekvenser for risikoen for hjerte- og karsykdom.

I de norske kostrådene fra 2011 konkluderes det med overbevisende dokumentasjon at utskifting av mettede fettsyrer med umettede gir redusert risiko for hjerte- og karsykdom. Ut fra disse entydige konklusjonene mener vi at utskifting av mettet fett med umettet fett burde ha vært det sentrale i de nasjonale retningslinjene.

\section{Middelhavskosthold versus nordisk kosthold}

I den nye retningslinjen trekkes det frem at «kostrådene som særlig har dokumentasjon for forebygging av HKS tar utgangspunkt i det tradisjonelle middelhavskostholdet» (5, s. 37). Arbeidsgruppen henviser til randomiserte, kontrollerte studier som dokumenterer at et slikt kosthold gir færre tilfeller av hjerte- og karsykdom i Spania. Særlig vektes Lyon- og Predimed-studiene tungt, og disse ligger bak en gjennomgående argumentasjon for anbefalingen om middelhavskosthold i retningslinjene.

Vi vil her poengtere at selv om middelhavskostholdet nevnes som selve hjørnesteinen i mange kostanbefalinger, må kostråd tilpasses lokal matproduksjon og tradisjon. I våre norske retningslinjer er det mer nærliggende å omtale et plantebasert, sunt nordisk kosthold - «plantebasert» bør være nøkkelordet. Selv om det ikke finnes studier med nordisk kosthold og harde endepunkter som sykelighet og død, finnes det nye undersøkelser som viser at et sunt nordisk kosthold har gunstig effekt på LDLkolesterolnivå og de andre risikofaktorene for hjerte- og karsykdom (14-17). Vi mener at disse studiene burde vies større plass i retningslinjene.

\section{Manglende systematikk}

I våre øyne er kostanbefalingene i retningslinjene preget av manglende systematikk. Et tilfeldig utvalg matvarer og studier er trukket frem, i stedet for vektlegging av kunnskapsbaserte kostråd. I retningslinjene heter det blant annet at ost er å foretrekke fremfor kjøtt- og kjøttvarer, ut fra argumentet om at «mettet fett fra kjøttvarer synes klarere assosiert med hjerte- og karsykdom enn mettet fett fra ost og meierivarer» (5, s. 37). Avokado og mørk sjokolade fremheves også i konkrete anbefalinger. Eksemplene er svært 
interessante forskningsspørsmål som studeres inngående, men vi mener at det ikke finnes god nok dokumentasjon for å sette søkelyset på disse i nasjonale retningslinjer.

\section{I utakt med Helsedirektoratets kostråd}

Med publiseringen av disse retningslinjene kan man si at Helsedirektoratet taler med to tunger. De nye nasjonale retningslinjene er ikke i tråd med Kostråd for å fremme folkehelsen og forebygge kroniske sykdommer - metodologi og vitenskapelig kunnskapsgrunnlag fra 2011 og rapporten Kostråd om fett - en oppdatering og vurdering av kunnskapsgrunnlaget fra 2017, som begge er publisert av Helsedirektoratet.

Vi opplever derfor at Helsedirektoratet med dette bidrar til å øke forvirringen rundt anbefalingene om sammenhengen mellom mettet fett, LDL-kolesterolnivå og hjerte- og karsykdom. Det er svært uheldig.

\section{LITTERATUR:}

1. Kostråd for å fremme folkehelsen og forebygge kroniske sykdommer: metodologi og vitenskapelig kunnskapsgrunnlag. Oslo: Helsedirektoratet, 2011.

2. Piepoli MF, Hoes AW, Agewall S et al. 2016 European Guidelines on cardiovascular disease prevention in clinical practice. Rev Esp Cardiol (Engl Ed) 2016; 69: 939. [PubMed][CrossRef]

3. Kostråd om fett - en oppdatering og vurdering av kunnskapsgrunnlaget. Oslo: Helsedirektoratet, 2017. Report No.: IS-2625.

https://helsedirektoratet.no/Lists/Publikasjoner/Attachments/1364/Kostr\%C3\%A5d\%20om\%2ofett\%20-\%2 oen\%2ooppdatering\%2oog\%2ovurdering\%20av\%2okunnskapsgrunnlaget\%2oIS-2625.pdf (4.10.2017).

4. Nasjonal handlingsplan for bedre kosthold (2017-2021). Sunt kosthold, måltidsglede og god helse for alle!

https://www.regjeringen.no/contentassets/fab53cd681b247bfa8co3a3767c75e66/handlingsplan_kostho ld_2017-2021.pdf(4.10.2017).

5. Nasjonal faglig retningslinje for forebygging av hjerte- og karsykdom.

https://helsedirektoratet.no/Retningslinjer/Forebygging\%2oav\%2ohjerte-\%2oog\%2okarsykdom.pdf (4.10.2017).

6. Ference BA, Ginsberg HN, Graham I et al. Low-density lipoproteins cause atherosclerotic cardiovascular disease. 1. Evidence from genetic, epidemiologic, and clinical studies. A consensus statement from the European Atherosclerosis Society Consensus Panel. Eur Heart J 2017; 38: 2459 - 72. [PubMed]

7. Baigent C, Blackwell L, Emberson J et al. Efficacy and safety of more intensive lowering of LDL cholesterol: a meta-analysis of data from 170,00o participants in 26 randomised trials. Lancet 2010; 376 : 1670 - 81. [PubMed][CrossRef]

8. Silverman MG, Ference BA, Im K et al. Association Between Lowering LDL-C and Cardiovascular Risk Reduction Among Different Therapeutic Interventions: A Systematic Review and Meta-analysis. JAMA 2016; 316:1289 - 97. [PubMed][CrossRef]

9. Müller H, Kirkhus B, Pedersen JI. Serum cholesterol predictive equations with special emphasis on trans and saturated fatty acids. an analysis from designed controlled studies. Lipids 2001;36: 783 - 91. [PubMed][CrossRef]

10. Keys A, Anderson JT, Grande F. Serum cholesterol response to changes in the diet: IV. Particular saturated fatty acids in the diet. Metabolism 1965; 14: 776 - 87. [PubMed][CrossRef]

11. Mensink RP, Zock PL, Kester AD et al. Effects of dietary fatty acids and carbohydrates on the ratio of serum total to HDL cholesterol and on serum lipids and apolipoproteins: a meta-analysis of 60 controlled trials. Am J Clin Nutr 2003; 77: 1146 - 55. [PubMed]

12. Katan MB. The response of lipoproteins to dietary fat and cholesterol in lean and obese persons. Curr Atheroscler Rep 2005; 7: 460 - 5. [PubMed][CrossRef]

13. Mozaffarian D, Micha R, Wallace S. Effects on coronary heart disease of increasing polyunsaturated 
fat in place of saturated fat: a systematic review and meta-analysis of randomized controlled trials. PLoS Med 2010; 7: e1000252. [PubMed][CrossRef]

14. Poulsen SK, Due A, Jordy AB et al. Health effect of the New Nordic Diet in adults with increased waist circumference: a 6-mo randomized controlled trial. Am J Clin Nutr 2014; 99:35- 45. [PubMed][CrossRef]

15. Uusitupa M, Hermansen K, Savolainen MJ et al. Effects of an isocaloric healthy Nordic diet on insulin sensitivity, lipid profile and inflammation markers in metabolic syndrome - a randomized study (SYSDIET). J Intern Med 2013; 274: 52 - 66. [PubMed][CrossRef]

16. Ulven SM, Leder L, Elind E et al. Exchanging a few commercial, regularly consumed food items with improved fat quality reduces total cholesterol and LDL-cholesterol: a double-blind, randomised controlled trial. Br J Nutr 2016; 116: 1383 - 93. [PubMed][CrossRef]

17. Adamsson V, Cederholm T, Vessby B et al. Influence of a healthy Nordic diet on serum fatty acid composition and associations with blood lipoproteins - results from the NORDIET study. Food Nutr Res 2014; 58: 24114. [PubMed][CrossRef]

Publisert: 30. oktober 2017. Tidsskr Nor Legeforen. DOI: 10.4045/tidsskr.17.0834

Mottatt 26.9.2017, første revisjon innsendt 3.10.2017, godkjent 4.10.2017.

(C) Tidsskrift for Den norske legeforening 2020. Lastet ned fra tidsskriftet.no 